\title{
A Survey on Preferred Slaughter Age of Goats in Tamil Nadu, India
}

\author{
J. Karthik*, Robinson J.J. Abrham, V. Appa Rao, M. Parthiban and R. Narendra Babu \\ Department of Livestock Products Technology (Meat Science), Madras Veterinary College, \\ Tamil Nadu Veterinary and Animal Sciences University, Chennai-7, Tamil Nadu, India \\ *Corresponding author
}

\section{A B S T R A C T}

Keywords

Goats, Slaughter age, Live weight.

Article Info

Accepted:

04 September 2017

Available Online:

10 October 2017
A survey was conducted to record the preferred age of slaughter of goat in meat related four district zones in Tamil Nadu. In Eight districts Age of the goats was assessed based the dentition pattern of milk tooth and number pair of permanent incisors before slaughter. Most of the goats slaughtered were less than 1 year age with the average body weight of $14-15 \mathrm{Kg}$ and with a carcasses weight of 6-7 Kg. In this study it is observed that animals mostly slaughtered in different slaughter houses across meat related zones in Tamil Nadu are below one year of age which indicates consumers' preference to tender meat over tougher meat from old animals. Hence a need based approach has to be made to improve the practices in goat rearing to attain desirable body weight at an early age which will fetch good returns.

\section{Introduction}

Goat meat is consumed by all the sections of society without any religious and social taboos hence it serves as a main source of red meat in the country. Sheep and goats are involved in the development of rural poor and about 5 million families subsist on activities related to sheep and goat rearing and utilising their produce. India is the largest exporter of sheep and goat meat, it has exported 23611.55 MT sheep and goat meat for a value worth Rs.828.11 crores during the year 2014-15 (APEDA). Major export destinations (201415) are United Arab Emirates, Saudi Arabia, Qatar, Kuwait and Oman. Goat is one of the major sources of meat in India, 37\% of goats are slaughtered per year and the meat production is 941 million $\mathrm{kg}$ (FAOSTAT,
2015). In spite of large potential, the meat trade in our country has not reached its due position as an industry because of unscientific rearing and slaughtering operations and improper recording of details of animals slaughtered as age of goat influences eating quality of meat and the need to document the age of animal is of importance in consumer perspective.

Since the meat of young animals tend to be tender when compared with mature animals.

Hence a survey work has been carried in the districts of Tamil Nadu to document the age of the animal, different breeds slaughtered, weights of animals and carcass. 


\section{Materials and Methods}

Tamil Nadu state has been classified into four distinct zones based on meat related variables. Two corporation/municipal slaughter houses from each zone were selected for the study. The primary data like breeds most slaughtered, Average live and carcass weight and age of the animals recorded by its dentition in animals presented to the respective slaughter houses in each district from the following corporation/municipal slaughter houses viz., Zone-1 (Villupuram and Salem), Zone-2 (Nilagiri and Kanyakumari), Zone-3 (Trichy and Kancheepuram) and Zone-4 (Madurai and Coimbatore).

\section{Results and Discussion}

Results of the present study revealed that different slaughtered in the Districts of Tamil Nadu are Salem black, Kanni, Kodi, Tellicherry. Average live weight of the animals ranged between $10-20 \mathrm{kgs}$ whereas carcass weight ranged between $5-10 \mathrm{~kg}$ which varied with breeds.Similarly Sivakumar et al., (2014) studied the effect of preslaughter weight on carcass characteristics and organoleptic characteristics of kanni goat meat and found that the pre slaughter weight in Gr-II $(15-18 \mathrm{~kg})$ was significantly $(\mathrm{P}<0.01)$ higher than Gr-I (12-15 kg). Sivakumar et al., (2014) studied the effect of preslaughter weight on carcass characteristics and organoleptic characteristics of kanni goat meat and found that the hot carcass weight in Gr-II $(15-18 \mathrm{~kg})$ was significantly $(\mathrm{P}<0.01)$ higher than Gr-I (12-15 kg).

Dadi et al., (2005) studied the effect of slaughter age on carcass characteristics of Borana male goat (12 months old) reared under intensive management in Ethiopia and reported that 15 months old goats had significantly higher $(\mathrm{P}<0.05)$ dressing percentage (Live weight) $(44.68 \pm 0.01 \%)$ than 15 months old goats $(44.57 \pm 0.01 \%)$.

Table.1 Data recorded in different slaughter houses

\begin{tabular}{|c|c|c|c|c|c|}
\hline Districts & Average slaughter per day & Breed & $\begin{array}{l}\text { Average live } \\
\text { weight (kg) }\end{array}$ & $\begin{array}{c}\text { Average } \\
\text { carcass weight } \\
(\mathbf{k g})\end{array}$ & $\begin{array}{c}\text { Age } \\
\text { (months) }\end{array}$ \\
\hline Kanchipuram & $\begin{array}{l}-20-25 \text { normal days, -Sundays, } \\
\text { holidays and festival season- } 40-50\end{array}$ & $\begin{array}{l}\text { Salem black, kanni and } \\
\text { Non descriptive goats }\end{array}$ & $10-20$ & $5-10$ & $6-8$ \\
\hline Villupuram & $\begin{array}{l}-10-15 \text { normal days, Sundays, } \\
\text { holidays and festival season }-40-50\end{array}$ & $\begin{array}{l}\text { Salem black, kanni and } \\
\text { Non descriptive goats }\end{array}$ & $10-16$ & $5-8.5$ & $6-12$ \\
\hline Trichy & $\begin{array}{l}\text { 20-30, Sundays, holidays and } \\
\text { festival season }-60-70\end{array}$ & $\begin{array}{l}\text { Kanni, Salem black and } \\
\text { Non descriptive goats }\end{array}$ & $12-18$ & $5-9$ & $6-9$ \\
\hline Salem & $\begin{array}{l}-30-40 \text { normal days, }- \text { Sundays, } \\
\text { holidays and festival season }-50-60\end{array}$ & $\begin{array}{l}\text { Salem black, kanni and } \\
\text { Non descriptive goats }\end{array}$ & $12-16$ & $5.5-8$ & $<12$ \\
\hline Coimbatore & $\begin{array}{l}-40-50 \text { normal days, -Sundays, } \\
\text { holidays and festival season }-100- \\
120\end{array}$ & $\begin{array}{l}\text { Salem black, kanni and } \\
\text { Non descriptive goats }\end{array}$ & $10-13$ & $4.5-6$ & $<6$ \\
\hline Kanyakumari & $\begin{array}{l}\text { 2-3, normal days, -Sundays, } \\
\text { holidays and festival season }-8-10\end{array}$ & $\begin{array}{l}\text { Kanni, Tellicherry, } \\
\text { Jamunapari and Non } \\
\text { descriptive goats }\end{array}$ & $10-14$ & $5-8$ & $6-8$ \\
\hline Madurai & $\begin{array}{l}-40-60 \text { normal days, Sundays, } \\
\text { holidays and festival season }-100- \\
120\end{array}$ & $\begin{array}{l}\text { Salem black, kanni, kodi } \\
\text { and Non descriptive goats }\end{array}$ & $11-14$ & $6-8$ & $<12$ \\
\hline Nilgiris & $\begin{array}{l}\text { 10-15- normal days, -Sundays, } \\
\text { holidays and festival season -25-30 }\end{array}$ & $\begin{array}{l}\text { Salem black, and Non } \\
\text { descriptive goats }\end{array}$ & $13-15$ & $5-6.5$ & $6-9$ \\
\hline
\end{tabular}


Hence it is observed that animals mostly slaughtered in different slaughter houses across meat related zones in Tamil Nadu are below one of year age which indicates consumers' preference to tender meat over tougher meat from old animals. Hence a need based approach has to be made to improve the practices in goat rearing to attain desirable body weight at an early age which will fetch good returns.

\section{References}

APEDA, 2016. http://apeda.gov.in/ apedawebsite/index.html
Dadi, H., Tatekwoldu and Tesfaye Lema, 2005. Comparison of carcass characteristics of Borana and Arsi Bale goats under durations of feedlot management. Livestock Research for Rural Development, 17(12): 1-7.

FAOSTAT, 2015. www.fao.org/faostat/es/

Sivakumar, P., Abraham, R.J. and Kulkarni, V.V., 2014. Effect of pre-slaughter weight on carcass traits and organoleptic characteristics of Kanni goats. Indian Journal of Small Ruminants (The), 20(1): 83-86.

\section{How to cite this article:}

Karthik, J., Robinson J.J. Abrham, V. Appa Rao, M. Parthiban and Narendra Babu, R. 2017. A Survey on Preferred Slaughter Age of Goats in Tamil Nadu, India. Int.J.Curr.Microbiol.App.Sci. 6(10): 285-287. doi: https://doi.org/10.20546/ijcmas.2017.610.035 